\title{
Psychological configurations and literary characters: A systems view
}

PIOTR SADOWSKI

For centuries literary criticism, it may be fair to say, was synonymous with character study, and the shift of critical attention from the characters themselves to other aspects of literary works is relatively recent. The legacy of the Romantic Revival with its glorification of individualism and human genius, and the interest in personality found in the nineteenth-century popular fiction could still inform the writings of such critics as A. C. Bradley, but the rest of our century shows a steady decline of character-oriented analysis of this kind. First the New Criticism moved more towards the problem of artistic design and aesthetic qualities of literary texts, and then in the last generation the critics' attention even shifted away from the texts themselves into the realm of socio-economic conditions, political ideologies, and the determinants of race, class, and gender which-it is argued-underlie the production of literary works. Today traditional humanistic and impressionistic character study is often considered naïve and old-fashioned, but as Brian Vickers has recently observed (1999: 80), "there is nothing wrong with [character criticism], for in mimetic genres such as drama or the novel the interaction of human beings constitutes the primary stage of literary experience." Common sense also seems to indicate that literary works are written by humans for other humans, and are for the most part concerned with human-like figures, and so the problem of character, both in relation to the actual personalities of authors and readers and in relation to fictitious literary personages, remains as valid as ever. The question is not whether one pursues character study or not (most of literary criticism is concerned with character in any case), but how it is done; that is, what theoretical assumptions about human personality and behaviour underlie the critic's interpretation of characters within literary, fictitious narratives.

The object of the present paper is to apply concepts and models of systems theory (Mazur, 1966, 1976) to generate statements and definitions relevant to the human psyche in general and to the characters described in literary texts in a more particular sense. Systems models and methods have emerged in mid- 
twentieth-century as a reaction to the fragmentation and overspecialisation of positivistic science, and their basic assumption was to view empirical reality as an integrated whole consisting of interacting systems (von Bertalanffy, 1973; Laszlo, 1972; Schmidt, 1982; Sadowski, 1999). In particular, the relevant premises of systems approach are the following:

$1 /$ The world exists and is intelligibly ordered, that is, open to rational inquiry;

2/ The world consists of systems organised in wholes and hierarchies extending from the molecular to astronomical levels. A system in turn can be defined as any set of interrelated elements;

3/ Systems interact with one another by exchanging information and energy. Information has to do with the nature of relations binding the elements of the system together, that is, with the system's structure. The nature of interactions between systems can be described by means of physical laws and rules of logic;

4/ Some systems have the ability to interact with the environment without altering their internal structures beyond a certain margin of tolerance, and to maintain or restore their functional equilibrium with regard to information and energy. Such systems will be called after Marian Mazur (1976: 134-140) selfregulating or autonomous. Examples of autonomous systems in the empirical world are plants, animals, and humans, that is, all living organisms.

The starting point in the definition and typology of characters presented in this paper is Mazur's cybernetic model of the autonomous system, whose structure and function is shown in the following schema:

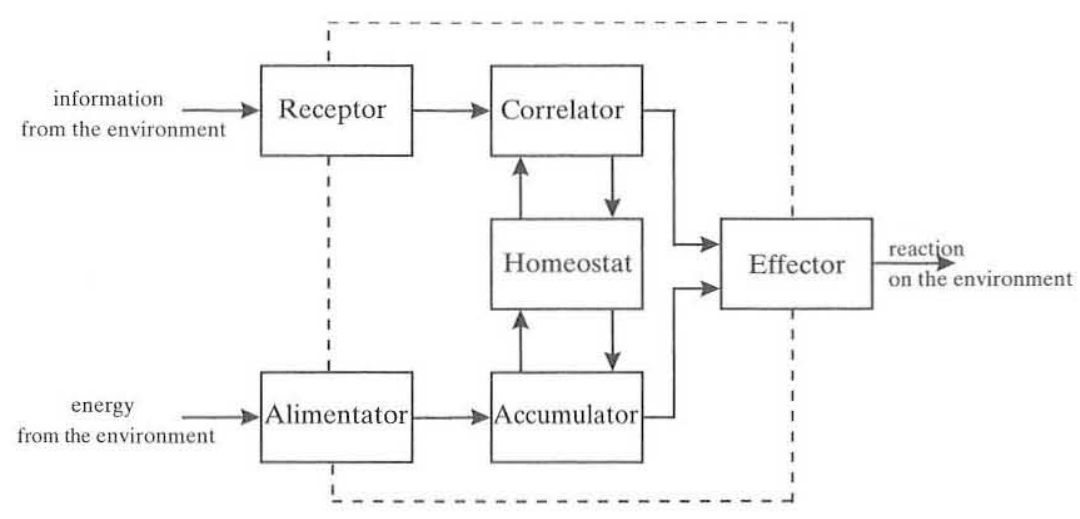

Fig. 1. The autonomous system (Mazur, 1976: 135).

The function of the main elements of the autonomous system can be described as follows:

- the receptor is an element by means of which the system receives information from the environment (e.g. the sensory channels); 
- the alimentator is an element through which the system receives energy from the environment necessary to sustain its life processes (e.g. food, oxygen);

- the effector is an element by means of which the system can react on the environment (e.g. touch, gesture, facial expression, voice);

- the correlator is an internal element of the system whose function is to transform and store information. In other words, the correlator is the system's "memory" which enables the system to interact with the environment to its advantage on the basis of past stimuli;

- the homeostat counteracts the internal transformations of information and energy that are potentially threatening to the system's functional equilibri$\mathrm{um}$, and allows the system to maintain the most advantageous level of interaction with the environment. For this purpose the homeostat is connected with the correlator and the accumulator through negative feedback, which means that weak inputs from either produce strong reactions of the homeostat and vice versa;

- the accumulator in turn is used by the system to transform and store energy (in the human body this function is performed by glycogen and fat tissue).

It is obvious that from the point of view of human psychology the most important are processes occurring in the correlator. Considering its function within the autonomous system it is possible to deduce the following useful statements and definitions:

1/ The reaction of the correlator on the homeostat will be called emotion. Depending on the intensity of this reaction we can talk about two extreme types of emotion: aversion, or negative emotion, caused by a strong reaction of the correlator, and attraction, or positive emotion, caused by a weak reaction of the correlator. Thus defined emotion is an internal reaction of the system which a/ participates in the system's interactions with the environment, and b/ is involved with energy, because the homeostat activated by emotion is also connected with the accumulator. The latter feature explains why emotions are often described metaphorically in terms referring to forms of energy: "to get hot under the collar", to experience "the fire of passion", or "to freeze with fear";

$2 /$ The reaction of the homeostat on the correlator will be called reflection. Depending on the intensity of this reaction we can talk about two extreme types of reflection: disapproval, or negative reflection, caused by a weak reaction of the homeostat, and approval, or positive reflection, caused by a strong reaction of the homeostat. Because of the negative feedback between the correlator and the homeostat an aversive emotion will meet, logically, with disapproval, and an attractive emotion will meet with approval;

3/ The ability of the system to activate registers of information deposited in the correlator will be called imagination. Due to the involvement of the homeostat imagination will be seen as an emotive reaction either to an external or to 
an internal stimulus, leading to an appropriate adaptive behaviour. The richer the imagination the greater the choice of reactions and the range of behavioural options;

4/ The sum of all registers of information in the correlator will be called psyche. (Henceforth in this paper I will be using the more traditional term "psyche" to denote the correlative processes within the system involving emotion, reflection, and imagination).

In view of the hierarchical nature of systems constituting empirical reality it is possible to treat an element of a system as a subsystem, which means that all properties pertaining to the main system will also apply to its subsystems. Let us assume that psyche (correlator) as a whole reveals the same general characteristics as the autonomous system (the human body) of which it is a part, and that psyche can interact with the environment and the rest of the system by striving to maintain functional equilibrium within its own structure. Following this assumption I propose the following schema for the human psyche as an autonomous system:

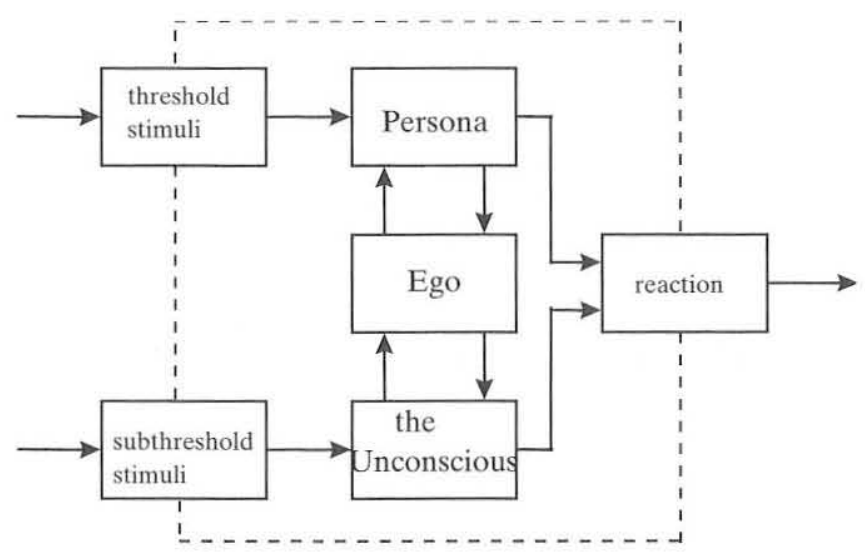

Fig. 2. Psyche as an autonomous system.

The diagram is structurally identical with Mazur's earlier schema (fig.1), which means that the distinguished components of the psyche should bear functional resemblance to the corresponding elements from the general model. With regard to the main internal elements of the psyche the postulated functional analogies are the following:

Persona - a part of the psyche responsible for the reception and storage of information from outside of the system. In other words, Persona is the main instrument of psychic adaptation to the socio-cultural environment. As the only psychic connection with the outside world Persona contains information per- 
taining to the various roles played by an individual within the group: the family, the community, the professional group and so on;

Ego - a part of the psyche containing information specific to the system and defining what is individual and unique about it. To be truly autonomous the system must possess properties and needs specific to itself, and must be able to choose reactions optimally satisfying those needs. In other words, by defining the individual properties of the system Ego represents self-identity, the subjective perception of one's "otherness" and distinctiveness from other systems. As a homeostatic centre of the psyche Ego must be able to select and approve those reactions that serve the realisation of self-identity and individual needs, and to avoid reactions that do not serve one's specific needs. To exercise its selfregulating function Ego must also possess the faculty of volition, understood as the ability to prompt reactions independently or even against socio-cultural pressures coming from Persona, and from the internal emotive pressures coming from the unconscious;

The Unconscious - a part of the psyche containing 1/ inborn responses to adaptively important environmental stimuli (the collective unconscious), and 2/ acquired and later repressed registers of information (the individual unconscious). The collective unconscious, in the traditional understanding of $\mathrm{C}$. G. Jung (1991: 226-227), and more recently in the formulation of evolutionary psychology (Plotkin, 1997; Pinker, 1998), includes adaptive, emotive responses to certain standard environmental stimuli acquired by humankind in the course of its evolution. The individual unconscious on the other hand includes ontogenetically acquired stimuli removed from consciousness as either unessential and unneeded or else disturbing and traumatic, and consequently relegated into the unconscious as otherwise potentially threatening to the person's psychic equilibrium. The analogy of the unconscious with the accumulator in the present model of the psyche comes from seeing the unconscious as emotionally, that is, energetically charged part of the psyche: the adaptive value of the inborn registers of the collective unconscious relies on their being linked with emotive responses prompting appropriate reactions; for example, a subthreshold perception of a predator at large triggering an automatic, that is, unconscious, reaction of fear and escape.

If Ego is to perform its homeostatic function as the centre of the psyche, it must be able to maintain balance between the demands of social life as determined by Persona, and the emotional pressures coming from the unconscious. Any imbalance is likely to create a potentially disturbing situation, including a partial loss of psychic independence, when Ego is responding only to one of the main sources of stimuli at the expense of the other. For example, an individual with a repressed unconscious and concerned only with social adaptation will be emotionally crippled (an insensitive careerist, a hypocritical puritan and so on). Generally speaking, the dominance of the Persona-Ego complex in the psyche 
will characterise an introvert personality, much in the understanding of C. G. Jung (1989: 549-551). On the other hand a person indulging his or her emotions (a romantic lover, a bohemian artist, a mystic and so on) can have, and often does, serious problems with social adaptation (weak Persona) due to emotional exuberance and problems with self-control. The dominance of the Ego-Unconscious complex in the psyche characterises therefore an extrovert personality. ${ }^{1}$

Examples of both types abound in life and literature alike, and it is interesting to observe that in literary narratives the introvert and extrovert types, representing as they do the opposite and complementary sides of the psyche, often appear in pairs: Iago and Othello, Bolingbroke and Richard II, Claudius and Hamlet, Sancho Panza and Don Quixote, Tom Buchanan and Jay Gatsby from F. S. Fitzgerald's novel-all representing the introvert and the extrovert types, respectively, paired up in the narratives to achieve the effect of psychological and dramatic wholeness.

On the other hand the situation in which the introvert and the extrovert tendencies are in relative harmony can be said to characterise a balanced personality. From the psychological point of view it is a highly desirable psychic configuration, characterised by inner stability and moderately successful social adaptation coupled by satisfying if less intensive emotional life, but in literature balanced personalities often make less attractive characters, largely due to their "unproblematic" nature. When placed centre stage in literary texts balanced characters, with their preoccupation with order, social convention, and moral principles, can sometimes experience engaging dilemmas (for example, $\mathrm{Mr}$. Duffy from James Joyce's story A Painful Case, vacillating between a spiritual relationship with a married woman and a trouble-free routine life of a bachelor), but when placed between introvert and extrovert characters the dramatic function of a balanced character is often reduced to providing a psychological link between the more extreme personalities. Such seem to be the role of the rather bland Desdemona placed between Iago and Othello; of the noble but colourless Horatio connecting, especially towards the end of the play, the cold and hostile world of the court with the sensitive and volatile Hamlet; of the static and sensible Nick Carraway mediating between the insensitive and cynical Tom Buchanan and the hopelessly romantic Jay Gatsby; or of the sensible Stella trying unsuccessfully to maintain some accord between her primitive and brutal husband Stanley and her fragile and emotionally vulnerable sister Blanch in Tennessee Williams' play A Streetcar Named Desire. It can also be argued that balanced characters, due to their impartiality and unassuming presence, make good narrators, as illustrated by Nick's role in The Great Gatsby, or by Horatio in Shakespeare's play, when he alone survives the palace slaughter to "speak to th'yet unknowing world how these things came about" (1990: 5.2.384-5).

It is clear, however, that pure introvert and extrovert types do not exist, because Persona and the unconscious are always connected through the homeo- 
static Ego. This means that neither does there exist an introvert person deprived of any emotions, nor can we talk about an extrovert person incapable of rational thinking or devoid of self-control. One can at best talk about a personality dominated by cold rationalism with repressed emotions, or a personality dominated by emotionalism resisting social pressure. For example, the coldblooded, cynical and "unfeeling" Iago is nonetheless motivated by such negative emotions as professional envy about Cassio's promotion, sexual jealousy about his wife Emilia and Othello, and by racial hatred towards Othello himself. The noble Moor on the other hand may fit first of all the stereotype of an exotic, romantic hero and idealistic lover, but he has also taken good care to become assimilated into the Venetian society as an able military commander (Persona). The opposition of the main personality types in the systems model explains why characters such as Iago and Othello, Bolingbroke and Richard, Sancho Panza and Don Quixote etc. often appear in pairs in literary texts: they represent fragmentary but mutually complementary aspects of the whole psyche, so that despite surface incongruity they instinctively seek and need one another; for example, the text of Othello provides ample evidence of the strange mutual attraction and interdependence between Iago and the Moor.

The general division into introvert, extrovert, and balanced types can be extended into further psychological categories. From the theoretical point of view the main components of the psyche as distinguished in figure 2: Persona, Ego, and the unconscious, can be treated as interacting subsystems of given reactivities. (Reactivity is the ability of the system to transform stimuli into reactions, and as such is an internal property of the system, independent from external influence.) For the clarity of argument let us consider only the extreme values of reactivity, that is, either strong or weak, and let us combine the three components of the psyche into possible configurations. The two extreme values of reactivity applied to the three elements produce in effect eight personality types, whose specifications are presented in a matrix below (fig.3), together with their brief description and exemplification.

\begin{tabular}{|c|c|c|c|c|c|c|c|c|c|}
\hline & & 1 & 2 & 3 & 4 & 5 & 6 & 7 & 8 \\
\hline \multirow[t]{2}{*}{ Persona } & strong & & & & & & & & \\
\hline & weak & & & & & & & & \\
\hline \multirow[t]{2}{*}{ Ego } & strong & & & & & & & & \\
\hline & weak & & & & & & & & \\
\hline \multirow[t]{2}{*}{ The Unconscious } & strong & & & & & & & & \\
\hline & weak & & & & & & & & \\
\hline
\end{tabular}

Fig.3. The Psychological Types. 
1-(weak Persona, weak Ego, strong unconscious). Such a configuration describes a highly emotional, imaginative, and sensitive character lacking in selfdetermination and in practical sense, and consequently exhibiting problems with social adaptation, being unable to cope with ordinary problems of life. In literature spiritual insight and sensitivity of character coupled with social vulnerability are typical for a naïve but noble and honest fool or a simpleton, as exemplified by the young Perceval from Chrétien's romance, by Lear's Fool, by Prince Myshkin from Dostoyevski's novel Idiot, or by the titular character from Isaac Bashevis Singer's story Gimpel the Fool;

2-(weak Persona, strong Ego, strong unconscious). Such a configuration describes an emotional and sensitive person with a strong sense of self-identity and psychological independence, possessing a set of individual norms and values that cannot be compromised by external collective standards. A character of this type will be called idealistic, exemplified by such literary protagonists as the romantic Lancelot, Don Quixote, Hamlet, the self-ostracised Raskolnikov from Dostoyevski's Crime and Punishment, the disgruntled poet Stephen Dedalus from James Joyce's Portrait of the Artist as a Young Man and Ulysses, Jay Gatsby, and generally romantic heroes;

3-(strong Persona, weak Ego, strong unconscious). Such a configuration describes a relatively unreflective, passive personality susceptible to influence either from a particular set of social norms, or from diverse emotions and moods, or both. It is a personality of a volatile, unstable conventionalist, who enjoys little psychological freedom but always remains at the mercy of some role or convention as well as his or her emotions. Conventional characters indulge and readily identify with a role that suits their particular mood, as illustrated by the foppish Osric from Hamlet, or by Duke Orsino and Countess Olivia from Twelfth Night, who both indulge in self-deceptive but ultimately harmless sentimental poses of a romantic lover and a mourning sister, respectively. The Little Chandler, a timid clerk who dreams of becoming a poet, from James Joyce's story The Little Cloud is another example of a conventional character, as is the self-deceiving Willy Loman, the main character from Arthur Miller's play Death of a Salesman;

4-(strong Persona, strong Ego, strong unconscious). Such a configuration describes a well-integrated and balanced psyche, optimally adapted to a particular social situation (worldly success and achievement), and at the same time enjoying a rich and satisfying emotional and spiritual life. The strong Ego (selfcontrol, strong sense of self-identity) is able to balance the excessive social pressures with inner urges and emotions, giving the individual a sense of inner confidence and self-fulfilment, and inspiring charismatic respect in others. A literary protagonist exhibiting the above traits will be called heroic, characterised accordingly by the achievement of full spiritual and worldly success due to his or her inner strength, ingenuity, and virtue. Examples of heroic characters are 
legion, and include the positive protagonists of the heroic myth and epic, traditional fairy tales, the chivalric romance, and generally romantic fiction. For example, a typical plot of a fairy tale involves a hero who wins a kingdom (Persona) and the hand of the princess (the unconscious) due to his own merit and virtue (Ego). Modern literary examples of heroic characters include Shakespeare's Henry V, the titular protagonists of Henry Fielding's novels Joseph Andrews and Tom Jones, or of Mark Twain's Tom Sawyer, in which the heroes achieve ultimate public and private success against all odds due to their own merit and determination;

5-(weak Persona, weak Ego, weak unconscious). Such a configuration describes a personality exhibiting problems with social adaptation (worldly failure), lacking will power and self-determination (apathy, cowardice), with low self-esteem and unimpressive emotional life (insensitivity, pettiness). These are the traits of a personal non-entity characterising an anti-heroic protagonist, such as the comic and cowardly braggart of the heroic epic (e.g. Braggadocchio from Book II of Spenser's The Faerie Queene) and commedia-dell'arte; the hapless stooges Rosencrantz and Guildenstern from Hamlet; Sir Andrew Aguecheek, the comic "knight" from Twelfth Night; the "good soldier" Shvejk from Jaroslav Hasek's comic novel; the down-and-outers from Beckett's novels and plays with their clownishness, personal insignificance and existential minimalism; or Franz Kafka's helpless and passive victims of soulless bureaucracy;

6-(weak Persona, strong Ego, weak unconscious). Such a configuration describes an independent, detached and emotionally repressed personality, unwilling to conform to the collective standards of social life (voluntary outcast). These traits characterise a dispassionate and displaced individualist, such as Horatio from Hamlet, the melancholy Jacques from As You Like It, Molière's Misanthrope, the alienated intellectual from Herman Hesse's Steppenwolf, or Nick Carraway, the detached narrator from the Great Gatsby, or generally a Nietzschean character;

7-(strong Persona, weak Ego, weak unconscious). Such a configuration describes an unemotional and insensitive personality which strongly but slavishly (due to weak Ego) identifies with a particular social role, sycophantically and opportunistically clinging to authority (no "moral backbone"). Literary characters of this type will be called conformist, as exemplified by the subservient rascal Oswald from King Lear, the overdutiful and prying Polonius, or the murderers hired by Macbeth and Richard III to eliminate dynastic rivals;

8-(strong Persona, strong Ego, weak unconscious). Such a configuration describes an unfeeling, insensitive, and unscrupulous personality strongly determined to achieve spectacular social success (power, wealth, prestige) or some other selfish goal. These are the characteristics of an authoritarian, despotic, and manipulative villain, abundantly exemplified by the negative protagonists of the mythical, epic, and romantic fiction and drama: Satan, King Herod, Mac- 
beth, Claudius, Richard III, Iago, Regan and Goneril etc. The less metaphysically evil and more moderate versions of the selfish and ruthless villain of modern fiction and drama include the insensitive and brutal Stanley Kowalski from Tennessee Williams' play, and the countless "bad guys" and "godfather" figures of detective fiction and film.

The eight character types generated by the systems model of the psyche form a complete set of possible psychological configurations, which means that any character, either in life or in life-simulating literary narratives, must belong to one of the distinguished categories. It is also important to point out that a particular configuration of the main components of the psyche: Persona, Ego, and the unconscious, underlying a given psychological type, depends - as said earlier-on specific reactivities of these elements, and these in turn derive from the intrinsic properties of the system that are independent from the environment. To be precise, the only component of the psyche subject to direct environmental influence is Persona as an instrument of social adaptation, through which external influence by way of upbringing, education, religious or political ideologies etc. can affect a person's character. The rest of the psyche, including Ego as the seat of self-identity and the enormous repository of the phylogenetic and ontogenetic experience deposited in the unconscious, remains beyond the sphere of direct environmental influence. Let me therefore introduce a definition, whereby the properties of the psyche independent from environment will be called character. ${ }^{2}$ In other words, while the psyche as a whole is common to all people, character as a specific configuration of psychic elements is what makes people differ from one another.

The obvious consequence of such a definition of character is that one's specific psychological configuration cannot be altered by external circumstances, and that it modifies a person's response to a situation in a way specific to the character. Stimuli and situation that agree with one's character will meet with positive emotions and approval, while stimuli and situations that do not agree with one's character will meet with negative emotions and disapproval. Also, because of the differences in characters stimuli attractive to one character will be aversive to another, and vice versa. It cannot be otherwise because Ego as the homeostatic centre of the psyche contains information specific to the person's individual needs, and as such it determines the choice of agreeable stimuli and the avoidance of disagreeable ones.

For example, it can be argued that the cause of Hamlet's acute mental discomfort, frustration, and ultimately his tragedy is the impossibility of reconciling his idealistic, extrovert character (type 2) with a situation requiring either someone of heroic proportions (type 4), or a determined individualist (type 6), or a self-advancing and opportunistic conformist (type 7). That Hamlet is the opposite of a Herculean hero is clear enough to him, when he says that his uncle is "no more like my father / Than I to Hercules" (1.2.152-3), and his famous de- 
lay in executing the revenge is not due to any external circumstances hindering his plan, but solely due to his juvenile, volatile, moody, self-conscious and idealistic mind, totally unsuited for the grim task of bloody revenge. Hamlet is in fact far from being inactive, but his actions - despite his constant verbal self-reminders of the imperative of revenge-lead him nowhere near the actual completion of the task, but are transferred instead into the sphere of pure philosophic speculation on the one hand, and-perhaps more importantly-into the sphere of play-acting, theatre, histrionics, posing and self-dramatisation, all in keeping with his extrovert character. As Horatio correctly assesses his friend's character early on in the play, Hamlet "waxes desperate with imagination" (1.4.87), and while he may have enough sense of reality to accept the Ghost's command of revenge, his artistic personality renders him incapable of getting a surer and firmer grasp of the practicalities of life to fulfil his grim and very inartistic task. Characteristically, ineffectual and futile in the realm of political action, Hamlet displays extraordinary ingenuity and cleverness when it comes to play-acting and drama. Upon the arrival of the players he immediately establishes himself as actor, producer, director, and collaborator in "The Murder of Gonzago" which he commissions to be performed before the king. The ostensible political purpose of the play, to catch the conscience of the king and expose his guilt, spectacularly miscarries, for despite Hamlet's elation at his "success" as a political stratagem the play has produced quite the opposite result: far from proving anything conclusive about the king's guilt Hamlet has in fact betrayed himself: the king now knows that Hamlet knows, and will now start making arrangements for Hamlet's departure to England with a view to having him killed there. So artistically the play may be a success, but tactically it is a serious failure and a setback in Hamlet's avenging mission.

Character therefore contains properties which do not depend and cannot be reduced to environmental factors, hence the situation in which Hamlet is obliged by custom and filial bond to follow the imperative of kin revenge, and adaptation to this situation can only be accomplished within the parameters of his character, including a necessary margin of tolerance, beyond which, however, the character will not go. The tolerance of character, like character itself, is an organic property of the system, independent from cultural norms, upbringing and so on, and not even the system itself using all its volition and self-persuasion can alter that. Interestingly, Hamlet's soliloquies are full of self-recriminations about his inability to perform the imposed task, but talking about the task does not bring Hamlet any nearer its completion; on the contrary, his elaborate, introspective, self-dramatising monologues are perfectly in agreement with his idealistic character-the initial reason for his inaction. It is difficult to agree therefore with Harold Jenkins, the editor of Arden Hamlet, when he says that "it is of course [emphasis mine] in the dramatisation of the Hamlet story, the role that determines the character, not the psychological make-up of the 
man that determines what he will do" (1990: 146). It is the other way round: the given character unable to adapt to the given situation produces the tragedy of Hamlet, because when the tolerance of character and the ability to compromise are pushed to the limit, adaptation is impossible and the only way to achieve functional equilibrium by the system is to lower its reactivity to zero, that is, cease to exist. Suicide is therefore an extreme but theoretically possible way of regaining homeostatic equilibrium, albeit at the cost of the system's existence. That Hamlet is dangerously close to this eventuality is testified by his mention of "self-slaughter" at the beginning of the play (1.2.132), and later by his central "to be, or not to be" soliloquy (3.1.56-88), which for the most part discusses suicide as a possible way out of the sea of troubles.

The matrix of psychological types can yield further functional implications and possible interactive configurations of relevance to character study in literature. For example, it is possible to arrange the types in a developmental sequence reflecting the growth of personality from childhood to old age. This can be done by using the following criteria: $1 /$ that the involvement of the unconscious with its play of emotions diminishes with age, and $2 /$ that the involvement of Persona as an instrument of mental adaptation to social life increases with age. In other words, the development of personality proceeds from extroversion through balanced personality to introversion. Following these criteria the developmental sequence of the psychological types can be arranged as illustrated in figure $3: 1$ / simpleton-childhood; 2 / idealist-teenage; $3 /$ conventionalist-adolescence; 4/ hero-youth; 5/ anti-hero-early adulthood; $6 /$ individualist-adulthood; $7 /$ conformist-early old age; and 8/ villain-old age. It should be pointed out, however, that the age categories are not to be confused with actual time of one's life, but more with the traditional concept of the "ages of man" (Burrow, 1988) as psychological or temperamental rather than strictly chronological categories. In this sense Hamlet may be thirty as far as calendar age is concerned, but temperamentally he is much "younger". Sometimes calendar age may be in opposition to psychological age, the fact exploited in literary texts to create misunderstandings, surprises or disappointments. For example, old Lear appears to be a balanced, "heroic" type, with a charismatic Persona ("every inch a king"), unbending Ego, and a great dose of human feeling. His two wicked daughters, Goneril and Regan, although obviously younger by a generation, appear nonetheless to be psychologically "older": self-advancing, ruthless, introvert villains. The beginning of Lear's tragedy is therefore a characterological mistake he makes with regard to his two daughters: as a man of principles (a balanced trait) he naively assumes that they would be loving and obedient to him simply because they are his daughters, that is, that their younger age would be matched by their "younger" characters. However, temperamentally Goneril and Regan are in fact much "older" than their father; hence the idea of Lear making 
his daughters his mothers in the Fool's clever assessment of the situation (1997: 1.4.168-69).

It could also be postulated that a literary work of sufficient length and complexity (not a short story or a brief poem but a novel or a play), that aims at achieving the effect of dramatic and psychological completeness and coherence, should include most, if not all, of the character types described in the systems model. For example, the main dramatis personae of King Lear seem to represent the full spectrum of character, starting with the extrovert characters: the Fool, the idealistic Kent, the conventional Edgar; then the balanced characters: the "heroic" Lear, anti-heroic Gloucester, Cordelia, and Albany; and ending with the introvert characters: the individualist Edmund, the conformist Oswald, and the villainous Regan, Goneril, and Cornwall. Interestingly, starting with the third act the cast becomes visibly polarised into Lear's maladapted "desperate train" of extroverts banished into wilderness, and the all-too-well adapted ruthless and opportunistic band of introverts gathered around the two wicked daughters representing "civilisation". The political and moral dichotomy of Lear's world is thus reinforced by the polarisation of characters in the psychological sense.

One could also argue that the classical division of dramatic genres into tragedies and comedies will correspond broadly with the two spheres of character: tragedy will mainly explore the relations among introvert characters, while comedy will mainly explore the relations among extrovert characters. King Lear may be exceptional in that its cast reveals a full spectrum of character types representing the absolute extremes of human experience, but in "pure" genres the dramatic plots are usually consistent with regard to respective character types. Thus the spectrum of characters in plays like Macbeth or Richard III extends from heroic to villainous, while in plays like A Midsummer Night's Dream or Twelfth Night the characters represent the opposite, extrovert part of the spectrum, extending from fools to heroes. An occasional ill-fitting introvert in the world of extrovert exuberance, humour and playfulness, like Malvolio in Twelfth Night, adds extra spice and by contrast increases the comic element foreign to him, just as the Porter scene in Macbeth, the only comic element in this darkest of tragedies, increases our feelings of horror at the murder of Duncan.

But what about the possible interactions between the characters? After all, a dramatic plot is not a pageant of isolated figures but a story involving complex character interactions in different situational contexts. In other words, a literary plot can be treated as a system understood as a set of interrelated and interacting elements. Let us then examine what kinds of interacting configurations are possible among the distinguished character types.

First of all, we can talk about three main kinds of character configurations (Mazur, 1976: 304-322): 1/ configurations involving identical types, $2 /$ configurations involving consecutive types, and $3 /$ configurations involving opposite 
types. By "consecutiveness" I understand the developmental order as discussed earlier. Then it is possible to talk about two main types of situations involving characters: 1 / situations in which the characters' interests are in agreement, and both the interactive tendency and emotions involved can be described as positive, and $2 /$ situations in which the characters' interests are in conflict, and both the interactive tendency and emotions involved can be described as negative.

People of identical characters have similar goals, interests and needs, and are therefore likely to form alliances to overcome common obstacles and achieve common goals. Consequently, positive tendencies among people of the same type of character will lead to solidarity and friendship. These are the types of relations uniting the villainous Regan, Goneril, and Cornwall in a concerted opposition against Lear. The sameness of character also keeps the anti-heroic Rosencrantz and Guildenstern together in their unfortunate mission to probe Hamlet's mind. On the other hand in negative tendencies among people of identical characters individual interests are in conflict, and we can talk about rivalry and antagonism. This is the nature of relations between Regan and Goneril towards the end of the play, when the two sisters turn against each other in the struggle for sovereignty, a conflict also embittered by sexual rivalry about Edmund.

The nature of interactions among people of consecutive characters is determined by the fact that in such a configuration one character is psychologically "older" than the other. That is to say, a psychologically older character possesses traits that the psychologically younger character has yet to achieve, and can therefore help and support the younger partner with the experience that the latter has not yet gained. The psychologically younger partner in turn will look upon the more mature person as his or her model and example. In positive tendencies, in which both sides have something to gain from a relationship, such a configuration will be characterised by a combination of adoration from the psychologically younger partner and protection from the older partner. These are the kinds of relations existing between the extrovert Fool, Kent, and Edgar, and the psychologically more mature Lear. In the case of negative tendencies and conflicting interests the psychologically younger partner is forced into a position of dependency or submission, while the psychologically older person will exploit his or her power and exercise dominance over the younger partner. This is what happens between the introvert Regan and Goneril and the balanced Lear before the latter's banishment into wilderness: despite what Lear expects considering his seniority and social custom the psychologically more mature wicked daughters unite to "mother" their father by treating him like a wayward, unruly, and capricious child. Likewise, the conformist and vacillating Macbeth is early in the play dependent on his psychologically older villainous wife, without whose determination he most probably would have "conformed" only to his newly acquired position as the Thane of Cawdor. 
Finally, in configurations involving opposite characters one partner possesses qualities which the other is lacking. That is, opposite characters are mutually complementary (as in the case of extrovert-introvert general types discussed earlier). Positive relationships between opposite characters will therefore be described in terms of mutual attraction and love, and will be characterised by a sense of completeness and full psychological satisfaction (happiness) felt by both sides. Such would be the initial nature of the relationship between Lear and Cordelia, Lear's most beloved daughter ("I lov'd her most," 1.1.122). On the other hand in negative relationships between people of opposite characters one partner will recognise in the other his or her rejected, opposite psychic elements, with the corresponding feelings of aversion and hatred. This process explains Lear's sudden dramatic change of feeling towards Cordelia in scene 1: her reticence in the love contest makes Lear lose his temper, curse and disown his beloved daughter in an outburst of hatred only equalled by the love he bore her.

Interestingly, configurations based on opposite characters are very popular in literary plots, probably because a pair of opposites, regardless of the nature of the internal combination of the psychic elements involved, always makes up a complete personality, thus creating an effect of a full dramatic contrast and psychological wholeness. For example, an opposition between an idealist and a conformist is effectively illustrated in King Lear by a conflict between the noble Kent, who loyally stood by the king and followed him into exile, and a superserviceable Oswald, the steward to Goneril. Kent could not be nearer the truth when he says: "No contraries hold more antipathy than I and such a knave" (2.2.83-84). A complementary opposition between a conventionalist and an individualist can be illustrated by a relationship involving Duke Orsino, a melancholy, conventional romantic lover, and the self-effacing but strong-willed Viola, or by the world of self-complacent bourgeois mediocrity and social convention despised by a lonely, introvert and dejected intellectual, the titular Steppenwolf from Herman Hesse's novel. It is also interesting to observe that in his relations with the king Hamlet always "plays a fool": incongruous as the fool and the villain are, they pair up very naturally as mutually complementary configurations of character. Hamlet puts on his antic disposition (buffoonery remaining within the margins of his idealistic character), precisely to establish some kind of relation with his villainous uncle - probably the only kind of relation possible for him under the circumstances.

The full set of possible character configurations involving identical, consecutive and opposite types in either positive or negative interactive tendencies is presented in figure 4. A full exemplification of all the above listed types of interactive configurations is not possible within the limited space of this paper, but it is clear that given the holistic nature of the character matrix presented in figure 3 the table offers a complete description of possible character interac- 


\begin{tabular}{|c|c|c|c|c|c|}
\hline \multicolumn{2}{|c|}{ Identical } & \multicolumn{2}{|c|}{ Consecutive } & \multicolumn{2}{|c|}{ Opposite } \\
\hline $\begin{array}{l}\text { positive: } \\
\text { solidarity, } \\
\text { friendship }\end{array}$ & $\begin{array}{l}\text { negative: } \\
\text { rivalry, } \\
\text { antagonism }\end{array}$ & $\begin{array}{l}\text { positive: } \\
\text { adoration/ } \\
\text { protection }\end{array}$ & $\begin{array}{l}\text { negative: } \\
\text { submission/ } \\
\text { dominance }\end{array}$ & $\begin{array}{l}\text { positive: } \\
\text { attraction, } \\
\text { love }\end{array}$ & $\begin{array}{l}\text { negative: } \\
\text { aversion, } \\
\text { hatred }\end{array}$ \\
\hline \multicolumn{2}{|c|}{$\begin{array}{c}\text { simpleton-simpleton } \\
\text { idealist-idealist } \\
\text { conventionalist- } \\
\text { conventionalist } \\
\text { hero-hero } \\
\text { anti-hero-anti-hero } \\
\text { individualist-individualist } \\
\text { conformist-conformist } \\
\text { villain-villain }\end{array}$} & \multicolumn{2}{|c|}{$\begin{array}{l}\text { simpleton-idealist } \\
\text { idealist-conventionalist } \\
\text { conventionalist-hero } \\
\text { hero-anti-hero } \\
\text { anti-hero-individualist } \\
\text { individualist-conformist } \\
\text { conformist-villain }\end{array}$} & \multicolumn{2}{|c|}{$\begin{array}{c}\text { simpleton-villain } \\
\text { idealist-conformist } \\
\text { conventionalist- } \\
\text { individualis } \\
\text { hero-anti-hero }\end{array}$} \\
\hline
\end{tabular}

Fig. 4. Character configurations.

tions underlying all literary plots. The table should also help to predict how given characters ought to behave in given situations, provided their descriptions in literary texts are consistent and coherent. For example, it could be noted that relations between balanced characters (the hero and the anti-hero), are listed both as consecutive and opposite types of interactions. This would mean that positive relationships between balanced personality types should be characterised by a rich mixture of adoration/protection and attraction and love all at the same time: such seems to be the character and intensity of feeling between Lear and Cordelia, which involves the father-daughter relationship with emotional attraction strong enough to make some critics suspect Lear of incestuous desires (Foakes, 1997: 39).

The character matrix (fig.3) can yield more configurations useful in character analysis, in addition to associating the distinguished types through identity, consecutiveness, and opposition. For example, it is possible to relate characters not only through identity but through similarity, that is, when two out of three main psychic components involved are found to match. It is easy to see for instance that the idealist is just as sensitive and emotional (strong unconscious), and just as socially vulnerable (weak Persona) as the simpleton, but the former is more psychologically independent (strong Ego) than the latter. This may explain the Fool's childish dependence on his "nuncle" Lear, as compared with the courage, self-determination, and resourcefulness of the noble Kent who only admires the king. Also, as the matrix shows the simpleton is just as weak-willed and socially maladapted as the anti-hero, but is more sensitive and spiritually inspired (strong unconscious) than the latter. The real simpleton can often be a "holy fool" imparting sacred wisdom, but the anti-hero will offer little insight except the negative admission of his ineffectuality, ignorance, and insignificance, as in the case of the two tramps from Beckett's Waiting for Godot. 
The full list of characters arranged by similarity as defined above includes the following configurations:

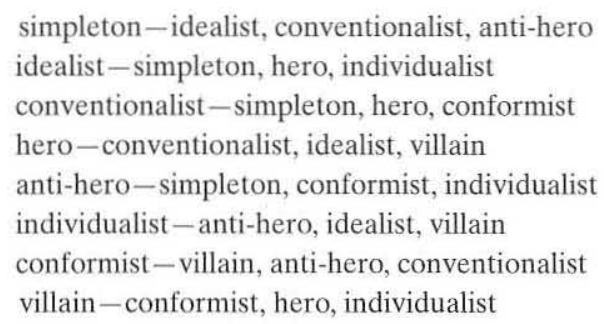

Of all possible variations of the eight character types the similarity between the hero and the villain is probably the most interesting. Both are well adapted to life (strong Personas) and determined to achieve their goals (strong Egos), except that the positively emotional and spiritual quality of the hero are contrasted with the lack of human feelings and insensitivity in the villain. Since for both types the achievement of this-worldly goals often requires a co-operation and approval of fellow humans, it is easy to see why villains often put on a hypocritical mask of nobility and virtue to dupe their naïve supporters, a common enough stratagem employed by crooked and cunning politicians, and vividly illustrated by Richard III's clever spectacle of piety, modesty, and detachment from worldly affairs put on before the gullible citizens, who promptly endorse Richard's ascension to the throne (Richard III, 3.7.94-246).

The systems theory of character here outlined can be further expanded, especially with regard to more detailed definitions and descriptions of the individual character types, to serve as a useful method of character analysis in literary texts. The main advantage of the systems model is the considerable degree of objectivity involved: given the initial premises and correct application of the rules of logic to transform deductively the premises into functional models, the empirical reality under investigation, here literary texts, can be adequately described and interpreted by a recourse to a general theory existing independently from literary evidence - methodologically a more reliable procedure than the subjective and often impressionistic, however insightful and well informed, evaluations of literary characters arising directly, that is, inductively, from the texts.

American College, Dublin

\section{Notes}

1. It is important to emphasise at this stage that all terms introduced in this paper to denote specific psychic functions or configurations are to be understood as stipulated 
in their definitions, rather than according to dictionary or other received meanings of these terms. This reservation is especially important in the classification of psychological types referred to here as "simpleton", "idealist", "hero" and so on: in all cases what matters are not the semantic intuitions about these terms but the psychological configurations generated by the theoretical model, and only conventionally denoted by what I thought were the most adequate terms taken from colloquial language.

2. Marian Mazur in his cybernetic theory defines character as "a set of stable controlling properties of the system" (1976: 221), that is, properties independent from the environment.

\section{References}

Bertalanffy, Ludwig von (1973) General Systems Theory: Foundations, Development, Application. Harmondsworth, Penguin Ltd

Burrow, John A. (1988) The Ages of Man: A Study in Medieval Writing and Thought. Oxford, Clarendon Press

Foakes, R. A. (ed.) (1997) William Shakespeare, King Lear. Walton-on-Thames, Thomas Nelson and Sons Ltd

Jenkins, Harold (1990) William Shakespeare, Hamlet. London-New York, Routledge

Jung, C. G. (1989) Psychological Types. London, Routledge \& Kegan Paul

Jung, C. G. (1991) The Structure and Dynamics of the Psyche. London, Routledge

Laszlo, Ervin (1972) Introduction to Systems Philosophy: Toward a New Paradigm of Contemporary Thought. New York, Harper and Row

Mazur, Marian (1966) Cybernetyczna teoria ukladow samodzielnych. Warsaw, PWN

Mazur, Marian (1976) Cybernetyka i charakter. Warsaw, PIW

Pinker, Steven (1998) How the Mind Works. London, Allen Lane

Plotkin, Henry (1997) Evolution in Mind: An Introduction to Evolutionary Psychology. London, Allen Lane

Sadowski, Piotr (1999) Systems Theory as an Approach to the Study of Literature: Origins and Functions of Literature. Lampeter, The Edwin Mellen Press

Schmidt, Siegfried (1982) Foundations for the Empirical Study of Literature: the Components of a Basic Theory. Hamburg, Helmut Buske Verlag

Vickers, Brian (1999) 'Review of the Arden Othello'. The Review of English Studies, New Series 50 (197). 80-81 